\title{
Surgical site infection in elderly patients
}

\author{
M Minutolo', G Blandino ${ }^{1}$, R Lanteri ${ }^{2 *}$, S Puleo ${ }^{2}$, V Minutolo $^{2}$ \\ From XXIII Annual Meeting of the Italian Society of Geriatric Surgery \\ Lecce, Italy. 2-4 December 2010
}

\section{Background}

The surgical site infection (SSI) is an unforeseen event that complicates patient post-operative care with a negative impact on results and may cause further surgery which could lead to the patient's death [1]. Furthermore, the bacteriological analysis of the surgical wound could be a predictive method of the surgical site infection after elective abdominal surgery [2,3]. Moreover postoperative infections lead to a growth of hospital costs, home medical care, social and psychological. Starting from this background it is clear how SSI control has a professional, ethical and economic value. Antibiotic prophylaxis is useful in preventing wound infection and limiting the negative effects of infection on the patient. The aim of this study is to evaluate the role of age and antibiotic prophylaxis in the incidence of surgical wound infection in patients undergoing elective abdominal surgery. Microbiological analysis of wound, surgical treatment, hospital and anesthesiological risk were evaluated.

\section{Patients and methods}

78 patients, divided in group A (21pt age $>70$ years) and group B (57pt age $<70$ years), were studied to assess the risk factors of abdominal surgical wound infection. Subcutaneous tissue swabs made after closure of the fascia and before suturing the skin were examined (Fig. 1). The indications for surgery were benign and malignant diseases such as abdominal hernias, gallstones, colorectal cancer, gastric cancer, kidney cancer, acute perforation of duodenal ulcer and choking hernia. All surgical interventions were classified as clean or clean / contaminated. Antibiotic prophylaxis was performed only in 48 patients 60 minutes before surgery. The presence of

\footnotetext{
* Correspondence: lanteri@unict.it

${ }^{2}$ Department of Surgical Sciences, Organ Transplantation and Advanced

Technologies University of Catania, Italy

Full list of author information is available at the end of the article
}

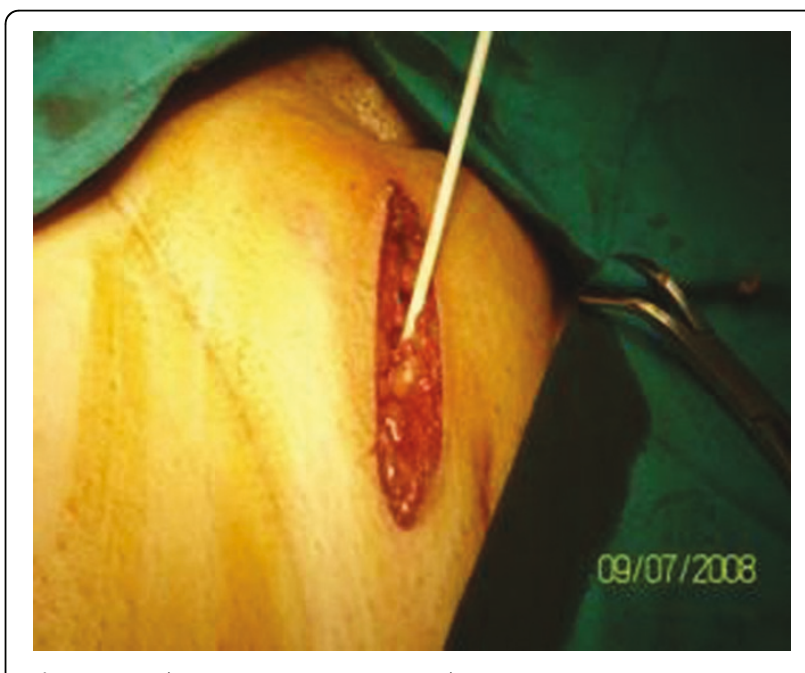

Figure 1 Subcutaneous tissue wound

wound infection was documented during the hospital stay and for up to 4 weeks after surgery.

\section{Results}

Of the 78 swabs, 30 were considered sterile. Of the 48 positive swabs microbiological analysis (47 isolations monomicrobici and only one polymicrobial) only 4 were associated with a wound infection (two strains of

Table 1 Our series. Surgical site infections. Our series 7/78 (8.97\%)

\begin{tabular}{lc}
\hline \multicolumn{1}{c}{ Isolated species ( patient ) } & Surgical mean time (min.) \\
\hline Escherichia coli ( group A ) & 120 \\
Escherichia coli ( group B ) & 130 \\
Enterobacter cloacae ( group B ) & $\mathbf{7 5}$ \\
Bacteroides fragilis ( group B ) & 140 \\
Bacteroides fragilis ( group B ) & 110 \\
Candida albicans (grouo B ) & 190 \\
Escherichia coli ( group A ) & $\mathbf{2 0 0}$ \\
\hline
\end{tabular}


Table 2 Relationship between surgical site infection, patient's age, surgical time and anesthesiological risk

\begin{tabular}{lllll}
\hline Patients & Surgical site contamination (\%) & Surgical site infection ( \% ) & Surgical mean time (min) & ASA SCORE \\
\hline Group A & $11 / 21(52.38 \%)$ & $2 / 21(9,52 \%)$ & 160 & III-IV \\
Group B & $37 / 57(64.91 \%)$ & $5 / 57(8,77 \%)$ & 129 & III \\
\hline
\end{tabular}

Table 3 Relationship between surgical site contamination and sex

\begin{tabular}{ll}
\hline Sex & Surgical site contamination (\%) \\
\hline M & $37 / 51(72.54 \%)$ \\
F & $11 / 27(40.74 \%)$ \\
\hline
\end{tabular}

Escherichia coli, one Enterobacter cloacae and one Candida albicans). Moreover, in two speeches, in which the swab of the wound showed no microbial growth, there was an infection caused by Bacteroides fragilis (table 1). The incidence of surgical wound infection in group A ( $>$ 70 years) was of $9.52 \%$, while in group B ( $<70$ years) of $8.77 \%$ and $4.25 \%$ overall in patients undergoing antibiotic prophylaxis and $12.90 \%$ of patients who had not performed antibiotic prophylaxis (Tables 2-3).

\section{Conclusions}

In our series no statistical differences were observed between the two groups in relation to the age.

\section{Author details}

'Department of Microbiological Sciences, Organ Transplantation and Advanced Technologies University of Catania, Italy. ${ }^{2}$ Department of Surgical Sciences, Organ Transplantation and Advanced Technologies University of Catania, Italy.

Published: 24 August 2011

\section{References}

1. Fiorio M, Marvaso A, Viganò F, Marchetti F: Incidence of surgical site infections in general surgery in Italy. Infection 2006, 34:310-314.

2. Mahmoud NN, Turpin RS, Yang G, Saunders WB: Impact of surgical site infections on length of stay and costs in selected colorectal procedures. Surg Infect 2009, 10(6):539-44.

3. Di Leo A, Piffer S, Ricci F, Manzi A, Poggi E, Porretto V, Fambri P, Piccini G, Patrizia T, Fabbri L, Busetti R: Surgical site infections in an Italian surgical ward: a prospective study. Surg Infect 2009, 10(6):533-8.

\section{Submit your next manuscript to BioMed Central} and take full advantage of:

- Convenient online submission

- Thorough peer review

- No space constraints or color figure charges

- Immediate publication on acceptance

- Inclusion in PubMed, CAS, Scopus and Google Scholar

- Research which is freely available for redistribution

Submit your manuscript at www.biomedcentral.com/submit 